\title{
Pesticide Determination in Water Samples from a Rural Area by Multi-Target Method Applying Liquid Chromatography-Tandem Mass Spectrometry
}

\author{
Mariana B. Almeida, ${ }^{a}$ Tiago B. Madeira, ${ }^{a}$ Lycio S. Watanabe, ${ }^{a}$ \\ Paulo Cesar Meletti ${ }^{b}$ and Suzana Lucy Nixdorf ${ }^{\circledR}, a$ \\ ${ }^{a}$ Departamento de Química, Universidade Estadual de Londrina (UEL), \\ Rod. Celso Garcia Cid/Pr, 445, km 380, Campus Universitário, 86057-970 Londrina-PR, Brazil \\ ${ }^{b}$ Departamento de Ciências Fisiológicas, Universidade Estadual de Londrina (UEL), \\ Rod. Celso Garcia Cid/Pr, 445, km 380, Campus Universitário, 86057-970 Londrina-PR, Brazil
}

\begin{abstract}
The rises of toxic effects caused by pesticides are of concern. However, Brazilian legislation still needs scientific subsides to improve the water quality requirements. This can be attributed in part to the few existing studies showing the occurrence and levels of multi-residue pesticides. Therefore, the objective of this study was to investigate the presence and the residue-levels of pesticides in surface, ground and drinking water of Tibagi River micro-basin in Paraná State, Brazil. Data obtained over a year for the physical-chemical parameters, screening and quantification, made by liquid chromatography-tandem mass spectrometry (LC-MS/MS), confirmed the contamination by several pesticides. Alarming concentrations of diuron and imazethapyr in a permanent preservation area and in groundwater were observed. The absence of legislation for most pesticides under study makes difficult the prohibition of their use and the control of their residue-levels on the environment. The results draw attention to further discussion and engagement around the pesticide regulations.
\end{abstract}

Keywords: residue level, environmental regulation, water quality requirements, diuron, imazethapyr

\section{Introduction}

Brazilian agriculture in the past few years has been growing and using an indiscriminate amount of pesticides to increase the crop yield becoming the main world's market. ${ }^{1-5}$ During 2013, the most commercialized pesticides were glyphosate and atrazine, both herbicides. However, fungicides, insecticides, acaricides, nematicides, growth regulators, repellents, and biocides are also commonly used. ${ }^{6}$

It is recognized that the agronomic intensification associated with the use of pesticides increases the environmental impacts, usually observed through physicochemical and microbiological parameters in water samples, for example. Consequently, the toxic effects on animals and humans, occupationally exposed, and to the environment also increase. ${ }^{4,7}$ Beyond the intensive use of different classes of pesticides, the lack of information and technical assistance in rural areas also contribute to soil and water contamination by the rural workers, as a result

*e-mail: snixdorf@uel.br of the incorrect discharge of residues during the clean-up of equipment and plastic containers on the environment. ${ }^{8}$

The pesticides disseminated throughout the environment have complex behavior, going through a variety of physics, chemistry and biological processes that generate metabolites and degradation products. ${ }^{9}$ Regardless of the concentrations, these products can present higher toxicity than the original compounds and may have a straight correlation with the increasing number of diseases, like cancer. ${ }^{10-14}$

Besides pesticides, the presence of other emerging contaminants in the environment, such as industrial compounds, pharmaceuticals, personal care products and disinfection by-products, results in negative effects in living organisms due to the non-target effect and contributes to increase surface and groundwater pollution. ${ }^{15,16}$ Recent studies have shown that the exposure of parents before a child's birth increases the risk of infant leukemia and Parkinson's disease to $70 \% .{ }^{17,18}$

At the South of Brazil, the Paraná State is known for the intensive production and commercialization of pesticides, occupying the third position according to the report made 
by the Ministries of Health in 2016 and of Agriculture in $2018 .{ }^{19}$ The discrepancy might be related to the presence of 36 industries of pesticides in the state. These large numbers of industries associated with agricultural activities indicate the need for severe environmental monitoring. The concern is related to the possibility of surface and groundwater contamination due to the presence of agrochemicals and the incorrect discharge of wastewater, which might affect the drinking water quality. Although many countries treat and distribute water to the population, in rural areas the water might come directly from natural sources, such as mines or wells without adequate treatment.

The water quality requirements are not a consensus and can follow national and international guidelines. In general, all the guidelines evaluate odor, taste, color, turbidity, conductivity, $\mathrm{pH}$ and concentration of organic and inorganic compounds, although compounds of interest and their maximum allowed values may vary for each country according to their use. ,20-22 $^{20}$

Currently, Brazil has monitoring programs of pesticides such as the National Monitoring Water Quality for Human Consumption Program (VIGIAGUA), available on the Monitoring Information on Water Quality for Human Consumption System (SISAGUA). However, according to the legislation, less than $10 \%$ of the pesticides in use are monitored. ${ }^{2,21,23}$ Recently, the Pesticides law (No. 7802 of 1989) is undergoing several changes, which is causing many divergences between businessmen, environmentalists and medical entities. ${ }^{24}$ One of the most controversial items includes permission for products classified as "acceptable risk", prohibiting only those classified as "unacceptable risk".

The Brazilian legislation already has several laws regarding known toxic compounds without allowed limit of concentration for drinking water. On the other hand, the European Union (EU) has no target pesticides, but is more restricted regarding the total concentration that should be less than $0.50 \mu \mathrm{g} \mathrm{L}^{-1}$ for drinking water. This fact emphasizes the need to review the matter of pesticide monitoring in the national legislation. ${ }^{25,26}$ Despite the discrepancy between national and international regulations, accordingly to Avelhan and Zylbersztajn, ${ }^{27}$ Brazil has the most advanced and restricted law concerning environmental protection, but its enforcement has several loopholes.

Regardless of the law and its application, some areas are well known by the suspect of pesticides contamination, as the case of a rural area in the Northern region of Paraná State. During the years of 2002 and 2006, the Public Ministry realized some investigations after suspecting poor water quality due to the non-natural taste and smell and the high fish mortality. ${ }^{28}$ However, several years later the problem persists, and little has been done to protect this area. Thus, considering the lack of scientific evidence and scarce data of pesticide multi-residue contamination in this region, the aim of the present study was to evaluate physico-chemical parameters and pesticides of the Tibagi River micro-basin water over a year. We hope this study will contribute providing scientific subsidies to promote the protection needed to this area by regulatory agencies. It is further expected that the data generated will serve as a basis for broadening the range of monitored pesticides besides reducing their residue levels in the environment.

\section{Experimental}

\section{Study area and samples}

The studied rural area is located in the city of Arapongas at the North of Paraná State (23.49S, 51.42W).The study area is recognized for its intense agricultural activity (mainly soy, wheat and corn) and to be close to an agrochemical industry. The water bodies present in this region are part of micro-basins, which constitute the basin of the Tibagi River. According to resolution No. 357/2005 from the Brazilian's National Council for the Environment (Conselho Nacional do Meio Ambiente, CONAMA), this river is classified as class $2 .{ }^{21}$ Its tributaries and springs, although not cataloged, must belong to the same class, or to a more protected class (class 1, or special class, the latter one designated for water mines). These water sources have being used by the population in plant cultivation, for animal breeding and for human consumption.

This region has a humid subtropical climate, and although there is no defined dry season, rains are more intense in the warmer months. Thus, considering the possibility of rainy periods and also the seasonal agricultural activity and pesticides uses, four collection campaigns were carried out in 9 sampling points during the year 2015: March (M), June (J), September (S) and December (D). The nine sampling sites were chosen taking into account the relevance and the presence of crops, proximity to the agrochemical industry, presence of water well, proximity to populated area, and the ease of access to streams potentially receiving runoff and effluents (Figure 1, and Table S1 in the Supplementary Information (SI) section).

The sources of water at each sampling point (SP) were collected as follows: 1, 3, 4, 5, 6 and 7, from stream or river, 2 from a mine, 8 from public supply and 9 from groundwater (water well). Although the major crops in this area are soy, wheat and corn, crops of tomatoes and eucalyptus were also noticed around the sampling points 


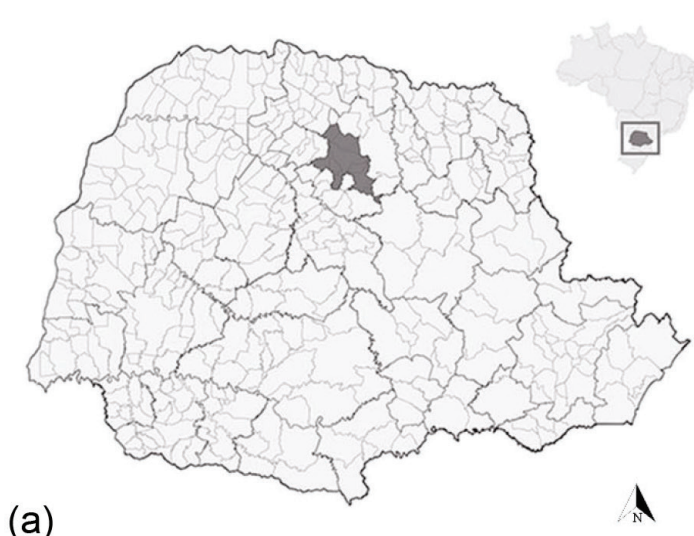

(a)

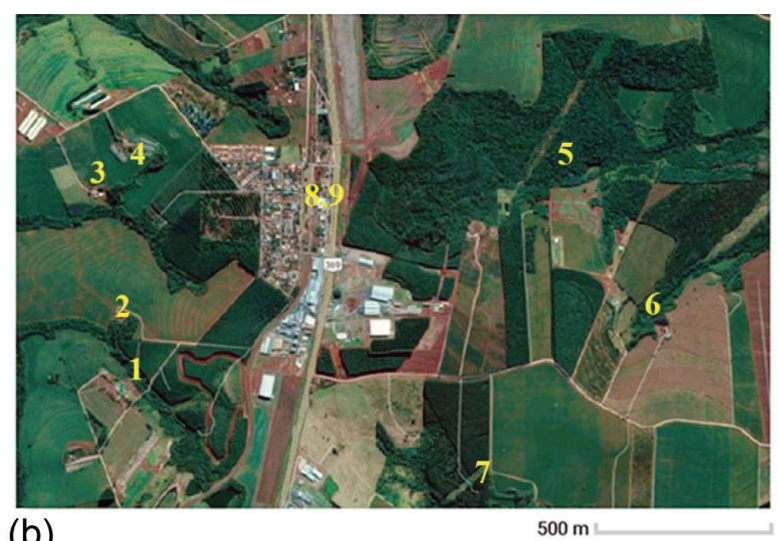

(b)

Figure 1. (a) Map location of the area under study at Paraná State and (b) an aerial view of the 9 points of water sampling collections.

(SP) 2 and 5, respectively (Figure 1). Most samples were collected from surface water bodies, being the sampling point SP 5 the only one under a permanent preservation area. The tap water sample (SP 8) has been treated according to the Brazilian requirements of sanitation and potability with limits established by the Ministry of Health ordinance No. 2914/2011.23

$1 \mathrm{~L}$ of water sample was collected in each sampling point in a clean amber glass bottle. Samples were kept under refrigeration $\left(4^{\circ} \mathrm{C}\right)$ until further processing.

\section{Physico-chemical parameters}

Water quality based on the physico-chemical parameters was evaluated according to the resolution No. 357/2005 from CONAMA. ${ }^{21}$ In natura samples were characterized in terms of: color at $\lambda=455 \mathrm{~nm}$ (Nanocolor ${ }^{\circledR}$ Vis MachereyNagel GmbH \& Co. KG, Düren, Germany), conductivity (Digimed DM-3P, Campo Grande, Brazil), pH (pH/Ion Meter 781, Metrohm, Switzerland) and turbidity (Hach 2100Q portable turbidimeter, Hach Corporation, United States).

\section{Sample preparation for pesticide analysis}

In natura water samples were vacuum filtered through a $0.22 \mu \mathrm{m}$ cellulose ester membrane (Millipore, USA) before solid phase extraction (SPE). The SPE procedure was done using Sep Pak C18 Cartridges (500 mg) (Waters, Milford, MA, USA) previously conditioned with $4 \mathrm{~mL}$ of methanol (HPLC grade, J. T. Baker, Center Valley, PA, USA) and equilibrated with $4 \mathrm{~mL}$ of ultrapure water (Milli-Q ${ }^{\circledR}$, Millipore, USA). $250 \mathrm{~mL}$ of the water sample were passed through the cartridges using a vacuum manifold system. After washing with $2 \mathrm{~mL}$ of ultrapure water, the cartridges were dried under a vacuum and kept frozen $\left(-12{ }^{\circ} \mathrm{C}\right)$ until further analysis. ${ }^{29}$ The elution was performed with
$2 \mathrm{~mL}$ of methanol, and the eluate was diluted 10 times in ultrapure water before liquid chromatography-tandem mass spectrometry (LC-MS/MS) analysis. Preconcentration factor reached 12.5 times.

\section{Standards}

Considering the agricultural activity and the use of the pesticides due to the crop areas, analytical standards of ametryn, atrazine, azoxystrobin, carbendazim, diuron, hexazinone, imazaquin, imazethapyr, imidacloprid, propiconazole, tebuconazole and tebuthiuron (purity between 96.5 and 99.9\%, Sigma Aldrich, Madrid, Spain) were used to prepare a stock solution of each pesticide at a concentration of $400.00 \mathrm{mg} \mathrm{L}^{-1}$ using methanol as solvent. Mixed standard solutions were prepared in methanol-water (10:90, v/v) in concentration range of 0.10-375.00 $\mu \mathrm{g} \mathrm{L}^{-1}$ and used to obtain analytical curves and further analysis of validation steps.

\section{Liquid chromatography conditions}

The LC-MS/MS method was performed by an Waters

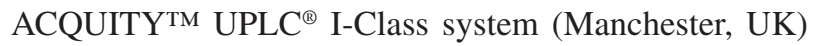
consisting of a binary pump with solvent manager, mobile phase degasser, autosampler with flow-through needle containing sample manager and column heater. Mobile phase was composed of solvent A (water) and solvent B (methanol) both with $0.1 \%$ formic acid. A linear gradient elution was employed: $5 \% \mathrm{~B}(0-0.24 \mathrm{~min}), 5-95 \% \mathrm{~B}$ (0.25-7.74 min), 95\% B (7.75-8.50 min) and 5\% B (8.51-10.00 min). The injection volume for each sample was $1.0 \mu \mathrm{L}$ in full loop injection mode and the sample manager was kept at $4{ }^{\circ} \mathrm{C}$. Chromatographic separation was achieved at $0.45 \mathrm{~mL} \mathrm{~min}{ }^{-1}$ flow rate using a Waters UPLC $^{\circledR}$ BEH C18 column $(2.1 \mathrm{~mm} \times 50 \mathrm{~mm}, 1.7 \mu \mathrm{m}$, Waters, Milford, MA, USA) maintained at $40{ }^{\circ} \mathrm{C}$. 


\section{Mass spectrometry conditions}

Mass detection was performed using a tandem quadrupole mass spectrometer, Waters ACQUITY ${ }^{\circledR}$ TQD (Manchester, UK), equipped with an electrospray ionization interface (ESI). The method for the screening of 402 pesticides was performed based on Morphet and Hancock. ${ }^{30}$ The presence or absence of the analyte defined was made by checking the existence of 2 transitions in the selective reaction monitoring (SRM) mode, in which the first transition is used for quantitation, while the second transition is applied to confirm the presence of the pesticide in the sample. Ion ratio was also performed. According to the compounds found during the screening step, 12 pesticides were evaluated due to relevance and availability of the analytical standards. The parameters used for external quantitation method were optimized individually for each one of the 12 pesticides under study (Table 1).

For both methods (screening and quantitation), the ion source was operated at $120{ }^{\circ} \mathrm{C}$ with a capillary voltage of $1.0 \mathrm{kV}$ and extraction cone voltage of $3.0 \mathrm{~V}$. Nitrogen was employed for both the dissolvent $\left(800 \mathrm{~L} \mathrm{~h}^{-1}\right)$ and cone $\left(5 \mathrm{~L} \mathrm{~h}^{-1}\right)$ kept at $400{ }^{\circ} \mathrm{C}$. Acquisition mode chosen was $\mathrm{SRM}$ at an argon collision gas pressure of $3.5 \times 10^{-3} \mathrm{mbar}$. Data acquisition and processing were achieved by using MassLynx ${ }^{\text {TM }} 4.1$ software (Waters, Manchester, UK).

\section{Validation process}

Before the analysis of the pesticides on the samples, the method was validated with respect to accuracy, precision, linearity and limits of detection (LOD) and quantitation (LOQ) following the EU Guidelines. ${ }^{31}$ The analytical range evaluated was from 0.01 to $50.00 \mu \mathrm{g} \mathrm{\textrm {L } ^ { - 1 }}$. The accuracy of the method was accomplished by recovery studies, performed by spiking known amounts of the standard mixture $(\mathrm{n}=3)$ with low $\left(0.25 \mu \mathrm{g} \mathrm{L}^{-1}\right)$, medium $\left(1.00 \mu \mathrm{g} \mathrm{L}^{-1}\right)$ and high $\left(50.00 \mu \mathrm{g} \mathrm{L}^{-1}\right)$ concentration levels of pesticides in ultrapure water. Accuracy was calculated as the percent ratio between the found and known concentrations.

Table 1. Mass spectrometry parameter of the quantified pesticides in water bodies

\begin{tabular}{|c|c|c|c|c|c|c|}
\hline$t_{R} / \min$ & Pesticide & Molecular formule & Precursor ion $/ \mathrm{m} / \mathrm{z}$ & Product ion $/ \mathrm{m} / \mathrm{z}$ & Cone voltage / V & Collision energy / eV \\
\hline \multirow{2}{*}{2.50} & \multirow{2}{*}{ carbendazim } & \multirow{2}{*}{$\mathrm{C}_{9} \mathrm{H}_{9} \mathrm{~N}_{3} \mathrm{O}_{2}$} & \multirow{2}{*}{192.1} & 132.10 & 33 & 28 \\
\hline & & & & 160.10 & 33 & 18 \\
\hline \multirow{2}{*}{3.27} & \multirow{2}{*}{ imidacloprid } & \multirow[b]{2}{*}{$\mathrm{C}_{9} \mathrm{H}_{10} \mathrm{ClN}_{5} \mathrm{O}_{2}$} & \multirow{2}{*}{256.1} & 175.10 & 34 & 20 \\
\hline & & & & 209.10 & 34 & 15 \\
\hline \multirow{2}{*}{4.65} & \multirow{2}{*}{ imazethapyr } & \multirow{2}{*}{$\mathrm{C}_{15} \mathrm{H}_{19} \mathrm{~N}_{3} \mathrm{O}_{3}$} & \multirow{2}{*}{290.11} & 69.05 & 42 & 28 \\
\hline & & & & 86.08 & 42 & 26 \\
\hline \multirow{2}{*}{4.97} & \multirow{2}{*}{ hexazinone } & \multirow{2}{*}{$\mathrm{C}_{12} \mathrm{H}_{20} \mathrm{~N}_{4} \mathrm{O}_{2}$} & \multirow{2}{*}{253.1} & 71.00 & 35 & 30 \\
\hline & & & & 171.10 & 35 & 16 \\
\hline \multirow{2}{*}{5.05} & \multirow{2}{*}{ imazaquim } & \multirow{2}{*}{$\mathrm{C}_{17} \mathrm{H}_{17} \mathrm{~N}_{3} \mathrm{O}_{3}$} & \multirow{2}{*}{312.2} & 86.20 & 40 & 28 \\
\hline & & & & 267.20 & 40 & 20 \\
\hline \multirow{2}{*}{5.11} & \multirow{2}{*}{ tebuthiuron } & \multirow{2}{*}{$\mathrm{C}_{9} \mathrm{H}_{16} \mathrm{~N}_{5} \mathrm{OS}$} & \multirow{2}{*}{229} & 116.00 & 36 & 26 \\
\hline & & & & 172.00 & 36 & 18 \\
\hline \multirow{2}{*}{5.42} & \multirow{2}{*}{ azoxystrobin } & \multirow{2}{*}{$\mathrm{C}_{22} \mathrm{H}_{17} \mathrm{~N}_{3} \mathrm{O}_{5}$} & \multirow{2}{*}{404} & 329.00 & 28 & 30 \\
\hline & & & & 372.00 & 28 & 15 \\
\hline \multirow{2}{*}{5.48} & \multirow{2}{*}{ ametryn } & \multirow{2}{*}{$\mathrm{C}_{9} \mathrm{H}_{17} \mathrm{~N}_{5} \mathrm{~S}$} & \multirow{2}{*}{228.1} & 68.10 & 38 & 36 \\
\hline & & & & 186.10 & 38 & 18 \\
\hline \multirow{2}{*}{5.62} & atrazine & $\mathrm{C}_{\mathrm{H}} \mathrm{ClN}$ & 2161 & 96.10 & 39 & 23 \\
\hline & atrazine & $8 \mathrm{H}_{14}-11 \mathrm{~N}_{5}$ & 210.1 & 174.10 & 39 & 18 \\
\hline 581 & diuron & $\mathrm{CH} \mathrm{ClNO}_{2}$ & 233 & 46.30 & 34 & 14 \\
\hline & 41. & ${ }_{9} \mathrm{I}_{10} \mathrm{Cl}_{2} \mathrm{~N}_{2} \mathrm{O}$ & & 72.10 & 34 & 18 \\
\hline & & & & 69.00 & 46 & 22 \\
\hline 6.36 & propıconazole & $\mathrm{C}_{15} \mathrm{H}_{17} \mathrm{Cl}_{2} \mathrm{~N}_{3} \mathrm{O}_{2}$ & 342 & 159.00 & 46 & 34 \\
\hline 724 & tebuconazole & $\mathrm{C} \mathrm{H}_{2} \mathrm{ClN} \mathrm{O}$ & 308 & 70.10 & 40 & 22 \\
\hline 1.24 & teouconazole & $\mathrm{C}_{16} \mathrm{H}_{22} \mathrm{CIN}_{3} \mathrm{O}$ & 308 & 125.00 & 40 & 40 \\
\hline
\end{tabular}

$\mathrm{t}_{\mathrm{R}}$ : retention time; $m / z$ : mass-to-charge ratio. 
The precision measurement of three different levels of concentration (0.01, 1.00 and $\left.10.00 \mu \mathrm{g} \mathrm{L}^{-1}, \mathrm{n}=6\right)$ was also performed and has been determined as percent coefficient of variation based on relative standard deviation (RSD in percentage). The limits of detection and of quantitation were also determined by the signal-to-noise $(\mathrm{S} / \mathrm{N})$ ratio.

\section{Statistical analysis}

A multivariate statistical technique was chosen to evaluate the large number of data obtained by quantitation of pesticides and physico-chemical analysis. The principal component analysis (PCA) allowed the reduction of the data set size, supporting the interpretation without loss of information. A 3D plot with factor scores were used to obtain a better view of principal component (PC) 1, 2 and 3. All the statistical analysis was accomplished through Statistica 8.0 software. ${ }^{32}$

\section{Results and Discussion}

The resolution No. 357/2005 from CONAMA establishes characteristics and concentrations of substances for water bodies according to the destination of these resources. In addition to appearance, organoleptic characteristics and microbiological parameters, this resolution specifies values for physico-chemical parameters and also maximum concentration limits for various substances, such as oil and its derivate, nutrients, metals and some pesticides, among other compounds. ${ }^{21}$ Unfortunately, only a few agrochemicals are listed in the resolution, and does not represent the most frequently used and detected pesticides in that area.

\section{Physico-chemical analysis}

Class 2 rivers and streams, as the water bodies under study, may be used without water treatment for irrigation and livestock, but for human consumption, adequate treatment is required. However, some of the physicochemical parameters analyzed showed values above the legal limits, highlighting conductivity, which was the parameter with more outliers according to the preconized standards (Table 2).

Conductivity is a physico-chemical parameter that may be used as an indirect measurement of pollutant concentrations since it depends on the dissolved ions in water, such as phosphate, nitrate and chloride ions, and common contaminants from crop areas. ${ }^{33,34}$ Despite its importance, no limit is described in the legislation. Nevertheless, it is

Table 2. Data from 9 different water sources in 4 sample collections during a year by month (M, J, S and D) regarding the color, conductivity, pH, and turbidity

\begin{tabular}{|c|c|c|c|c|c|c|c|c|c|c|}
\hline \multirow{2}{*}{ Parameters } & \multirow{2}{*}{ Month } & \multicolumn{9}{|c|}{ Sampling point (SP) } \\
\hline & & 1 & 2 & 3 & 4 & 5 & 6 & 7 & 8 & 9 \\
\hline \multirow{4}{*}{ Color / (mg Pt L L $)$} & M & 39.82 & 13.55 & 39.82 & 25.49 & 39.82 & 18.32 & 20.71 & 11.16 & 13.55 \\
\hline & $\mathrm{J}$ & 56.53 & 25.49 & 30.26 & 35.04 & 54.14 & 30.26 & 30.26 & 23.10 & 25.49 \\
\hline & S & $104.20^{\mathrm{a}}$ & 37.43 & 32.65 & 56.53 & $99.52^{\mathrm{a}}$ & 30.26 & 42.20 & 32.65 & 37.43 \\
\hline & $\mathrm{D}$ & $226.09^{\mathrm{a}}$ & $130.56^{\mathrm{a}}$ & $111.46^{\mathrm{a}}$ & $230.86^{\mathrm{a}}$ & $467.28^{\mathrm{a}}$ & $123.40^{\mathrm{a}}$ & $123.40^{\mathrm{a}}$ & $101.91^{\mathrm{a}}$ & $187.88^{\mathrm{a}}$ \\
\hline \multirow{4}{*}{$\begin{array}{l}\text { Conductivity / }\left(\mu \mathrm{S} \mathrm{cm}^{-1}\right) \\
\text { at } 25^{\circ} \mathrm{C}\end{array}$} & M & 93.90 & 82.10 & $146.80^{\mathrm{b}}$ & $325.00^{\mathrm{b}}$ & 2.90 & 28.80 & 4.20 & $138.50^{\mathrm{b}}$ & $421.00^{b}$ \\
\hline & $\mathrm{J}$ & 98.00 & 85.00 & $150.50^{\mathrm{b}}$ & $296.00^{\mathrm{b}}$ & 2.50 & 28.10 & 4.10 & $134.50^{\mathrm{b}}$ & $409.00^{\mathrm{b}}$ \\
\hline & S & 76.40 & 72.60 & $133.20^{\mathrm{b}}$ & $269.00^{\mathrm{b}}$ & $1375.00^{\mathrm{b}}$ & 31.00 & 3.50 & $120.30^{\mathrm{b}}$ & $344.00^{\mathrm{b}}$ \\
\hline & $\mathrm{D}$ & 81.60 & 73.20 & 96.90 & $219.00^{\mathrm{b}}$ & $1286.00^{\mathrm{b}}$ & 30.50 & 3.40 & $131.20^{\mathrm{b}}$ & $360.00^{\mathrm{b}}$ \\
\hline \multirow{4}{*}{$\mathrm{pH}$} & M & 6.04 & 6.19 & $5.91^{\mathrm{a}}$ & 6.30 & 6.92 & 6.38 & 6.43 & 7.08 & 6.84 \\
\hline & $\mathrm{J}$ & $5.96^{\mathrm{a}}$ & 6.28 & $5.87^{\mathrm{a}}$ & 6.32 & 6.65 & 7.02 & 6.45 & 7.00 & 6.70 \\
\hline & S & 6.10 & $5.60^{\mathrm{a}}$ & 6.53 & 6.67 & 6.83 & 7.44 & 6.81 & 7.36 & 7.29 \\
\hline & $\mathrm{D}$ & 6.86 & $5.73^{\mathrm{a}}$ & $5.78^{\mathrm{a}}$ & 6.90 & 6.89 & 6.82 & 6.45 & 7.03 & 6.93 \\
\hline \multirow{4}{*}{ Turbidity / NTU } & M & 5.69 & 3.78 & 0.46 & 4.52 & 6.66 & 2.15 & 1.04 & 0.18 & 1.90 \\
\hline & $\mathrm{J}$ & 3.63 & 0.54 & 0.39 & 1.59 & 5.49 & 0.57 & 0.67 & 0.22 & 0.30 \\
\hline & S & 6.72 & 1.35 & 0.43 & 4.48 & 8.90 & 0.76 & 0.54 & 0.27 & 0.65 \\
\hline & $\mathrm{D}$ & 20.20 & 2.02 & 0.55 & 19.40 & 93.20 & 1.76 & 1.05 & 0.17 & 4.11 \\
\hline
\end{tabular}

M: March; J: June; S: September; D: December; ${ }^{a}$ data values higher than the legislation limit (resolution 357/2005 from the Brazilian National Council for the Environment (CONAMA)); limits according to the resolution No. 357/2005 from CONAMA: color $<75.00 \mathrm{mg} \mathrm{Pt} \mathrm{L}^{-1}$, $\mathrm{pH}$ value between 6.00 and 9.00, and turbidity < 40.00 NTU for class 1 and $<100$ NTU for class 2 and 3; blimits preconized by Brazilian National Health Foundation (Fundação Nacional de Saúde (FUNASA): ${ }^{32}$ conductivity $<100.00 \mu \mathrm{S} \mathrm{cm}^{-1}$. 
known that natural water receiving domestic or industrial effluent, on the other hand, can present conductivity above than $1000.00 \mu \mathrm{S} \mathrm{cm}^{-1} \cdot{ }^{33} \mathrm{~A}$ study performed in two rivers at the Rio Grande do Sul State showed conductivity values lower than $90 \mu \mathrm{S} \mathrm{cm}^{-1}$ for samples considered as natural waters. ${ }^{35}$ Values higher than $100.00 \mu \mathrm{S} \mathrm{cm}^{-1}$, as in cases of SP 3, SP 4 and SP 9 with results in the range of 120.30 to $421.00 \mu \mathrm{S} \mathrm{cm}^{-1}$, may indicate environmental impact in natural water. SP 5 conductivity stands out due to the raised levels observed in the samplings in September and December (Table 2) with an increase more than 600 times the value of $1200.00 \mu \mathrm{S} \mathrm{cm}^{-1}$, pointing out pollution.

All December samplings showed color values higher than $75.00 \mathrm{mg} \mathrm{Pt} \mathrm{L} \mathrm{L}^{-1}$ probably due to the rainy period (59.8 $\mathrm{mm}$ of precipitation) that increases the amount of available organic matter and suspended solids.

The $\mathrm{pH}$ value is one of the most important physicochemical parameters evaluated in this work since the persistence and the partitioning of the pesticides molecules in the aqueous media is directly related to it. ${ }^{35}$ The $\mathrm{pH}$ range observed was 5.6 to 7.44 , of which six samples were considered outliers accordingly to the limit range (6.00-9.00). ${ }^{21}$ In this $\mathrm{pH}$ range, several compounds still persist on their non-ionized form due to the $\mathrm{p} K$ a value, promoting their association with the organic matter available. ${ }^{36}$

Regarding the turbidity, a water of natural source usually ranges from 3.00 to 500.00 nephelometric turbidity units (NTU), while in drinking water, the turbidity should be lower than 1.00 NTU. The turbidity of the samples ranged from 0.17 to 93.20 NTU. Since the classification that the rivers are class 2 , all the samples can be considered as in accordance with the quality standards for this parameter. However, SP 5 (D) presented a worrisome value of 93.20 NTU, higher than all the other samples and close to the allowed limit.

Another requirement for class 2 is the virtual absence of substances that provide taste or odor. All the samples collected, except the SP 8 (tap water), had a non-natural smell, a fact that could be used to classify the sampling points as unfit for use. However, these waters have been continuously used by the local population for vegetables, fruit and grain irrigation, for breeding animals, and also for human consumption.

\section{Pesticide screening}

Most of the standard water and wastewater treatments do not eliminate certain substances, such as pesticides. For this reason, if the drinking water is obtained from surface and groundwater, the pesticide residues presented in the sources can also reach and expose humans. ${ }^{2}$

Due to the strong agricultural activity, the evaluation of the presence of pesticides as main contaminants was performed firstly by a qualitative screening method for 402 different pesticides. ${ }^{30}$ Despite the selectivity of SRM mode, it is common to get false positive or negative results due to matrix interferent effect and slight changes in retention time. ${ }^{37}$ After a meticulous data analysis, only the compounds that presented both transitions in the duplicate analysis were considered as a positive result. Therefore, the presence of at least 26 different pesticides in the samples was confirmed. Samples SP 4, SP 5, SP 7 and SP 9 were the most contaminated points in all the samplings (data not shown). SP 5 showed more than 15 different compounds by sampling. The total ion chromatogram (TIC) of SP 5 for the four collections (Figure 2) also shows the different profiles

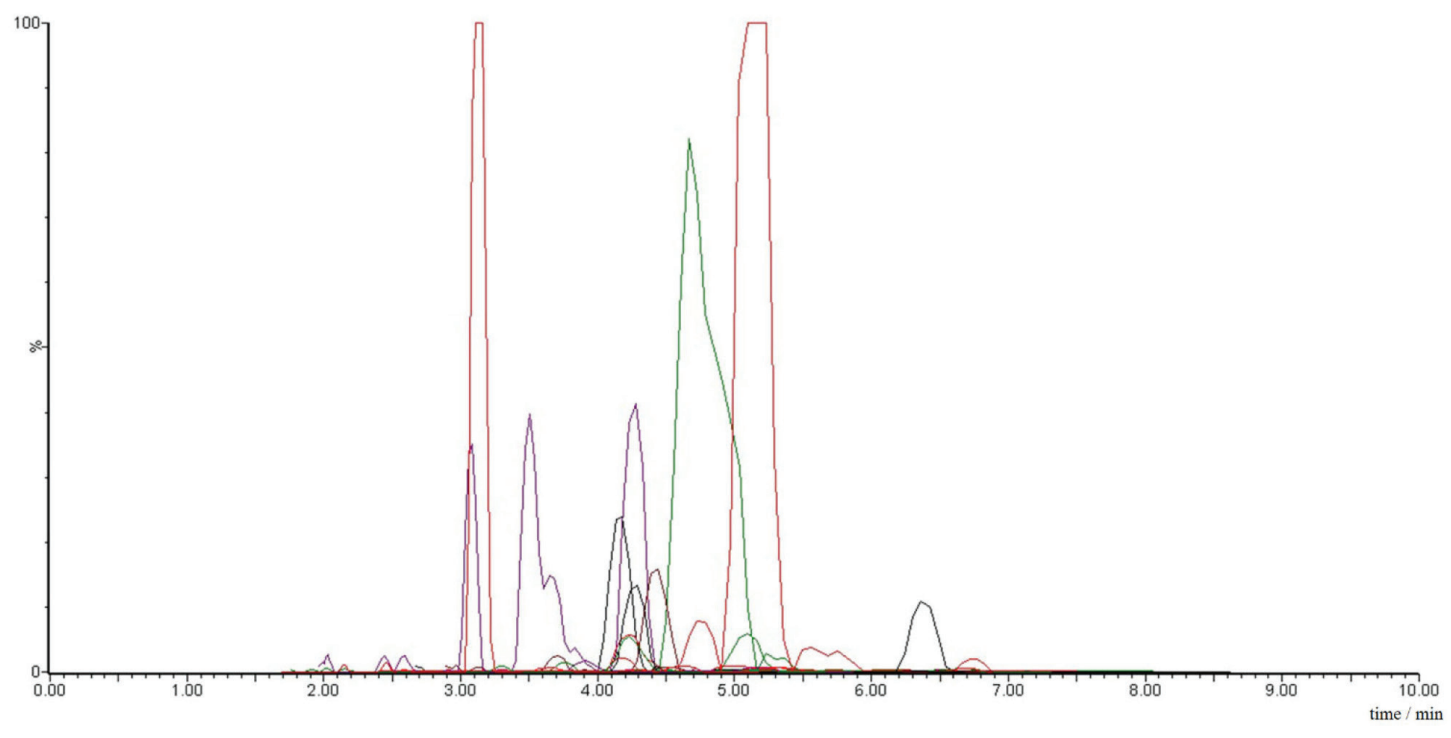

Figure 2. Total ion chromatogram at the screening of pesticides acquired in SRM mode for SP5. 
of each month and the different intensities of compounds present in this sample at the screening stage.

\section{Quantitative method validation}

Among the pesticides confirmed during the screening step, a quantitative method to evaluate 12 pesticides was developed and optimized (Table 1). The results are present in Table S2 in the SI section. Linearity was achieved presenting coefficients of determination $\left(\mathrm{R}^{2}\right)$ higher than 0.99 for all studied pesticides in a concentration range of 0.01 to $50.00 \mu \mathrm{g} \mathrm{L} \mathrm{L}^{-1}$. Precision was assessed based on values found in the real water samples, and all the studied compounds presented relative standard deviations lower than $20 \%$. The accuracy of the method calculated through the 3-level recovery on low, medium and high standard concentrations $\left(0.25,1.00\right.$ and $50.00 \mu \mathrm{g} \mathrm{L}^{-1}$, respectively) were within the acceptable levels of 70 to $120 \%$. LOQ was considered as the lowest concentration point on a calibration curve, ${ }^{38}$ at $0.01 \mu \mathrm{g} \mathrm{L}{ }^{-1}$ for all pesticides, except for the imazethapyr $\left(\mathrm{LOQ}=0.05 \mu \mathrm{g} \mathrm{L}^{-1}\right)$ and azoxystrobin $\left(\mathrm{LOQ}=0.10 \mu \mathrm{g} \mathrm{L} \mathrm{L}^{-1}\right)$.

The method was considered feasible and reliable for the target pesticides and the obtained values were in accordance with the EU Guidelines. ${ }^{31}$

\section{Pesticides quantification in samples}

Pesticide quantification was performed after method validation in the 36 samples, which were analyzed in triplicate with RSDs under $20 \%$ for each pesticide. The total concentration obtained of pesticides per sample is summarized in Table 3, with values ranging from 0.28 to $20.63 \mu \mathrm{g} \mathrm{L} \mathrm{L}^{-1}$. For individual results of pesticide per sample and collection period $(\mathrm{M}, \mathrm{J}, \mathrm{S}$ and $\mathrm{D})$ presented as mean \pm standard deviation see SI section, Tables S3 to S6.

The presence or absence of a pesticide in water can be related to its persistence or movement throughout the soil. The physico-chemical properties of each pesticide (half-life sorption potential $\left(\mathrm{K}_{\mathrm{oc}}\right)$, and solubility in water) can be used to calculate the partitioning index known by groundwater ubiquity score (GUS). The GUS index can indicates the trend of mobility to water bodies and groundwater in extremely low, low, moderate and high displacement, although it does not take into account the local environmental conditions. ${ }^{36,39,40}$ Accordingly, to the GUS index, the compounds under study presented moderate (propiconazole $<$ diuron $<$ azoxystrobin $<$ ametryn $<$ tebuconazole) and high (carbendazim $<$ atrazine $<$ imidacloprid $<$ hexazinone $<$ imazaquim $<$ tebuthiuron $<$ imazethapyr) potential for movement. ${ }^{39,40}$ Nevertheless, the concentrations obtained during the sample analysis showed a behavior different than expected for some compounds, such as diuron.

Within the legislated organic compounds, atrazine is the only pesticide which was evaluated in this study, with a maximum limit level of $2.00 \mu \mathrm{g} \mathrm{L}^{-1} .{ }^{21}$ The SP 9 (J) sample presented the highest concentration of atrazine concentration $\left(1.40 \mu \mathrm{g} \mathrm{L}^{-1}\right)$. At the same time, imazethapyr was present in a concentration of $6.54 \mu \mathrm{g} \mathrm{L}^{-1}$ in SP 7 (J) and diuron at $12.59 \mu \mathrm{g} \mathrm{L}^{-1}$ in SP 7 (D). Diuron is one of the most widely used herbicides in Brazil, and although it is persistent in soil due to its low solubility in water, several studies have been made to measure its concentration in water bodies and to evaluate its toxicity in different organisms..$^{9,41}$ A study performed with samples collected from two rivers from Mato Grosso do Sul State, an area with a strong agricultural activity obtained concentrations of diuron lower than $0.01 \mu \mathrm{g} \mathrm{L}{ }^{-1} .{ }^{15}$ The lowest concentration of diuron in the present work was $0.16 \mu \mathrm{g} \mathrm{L}^{-1}$. The presence of atrazine, carbendazim, imidacloprid, hexazinone and tebuthiuron in the Mato Grosso do Sul State was also evaluated by the researchers, with concentrations lower than $0.1 \mu \mathrm{g} \mathrm{L}^{-1} .{ }^{15}$ Effective concentrations (EC, 50\%) of diuron were reported in the literature at the same range of those found in SP 5, 7 and 9 (1.03-12.59 $\left.\mu \mathrm{g} \mathrm{L}^{-1}\right)$. $^{42}$

Researchers also have been studying imazethapyr and tebuconazole concentrations in surface water surrounded by rice crop areas, where the maximum concentrations reported for these compounds were 0.326 and $0.015 \mu \mathrm{g} \mathrm{L}^{-1}$,

Table 3. Total concentration of the 12 pesticides quantified by LC-MS/MS in water bodies of a rural area studied at north Paraná State

\begin{tabular}{|c|c|c|c|c|c|c|c|c|c|}
\hline \multirow{2}{*}{ Month of collection } & \multicolumn{9}{|c|}{ Total pesticide concentration $/(\mu \mathrm{g} \mathrm{L}-1), \mathrm{n}=3$} \\
\hline & SP 1 & SP 2 & SP 3 & SP 4 & SP 5 & SP 6 & SP 7 & SP 8 & SP 9 \\
\hline $\operatorname{March}(\mathrm{M})$ & 0.29 & 0.44 & 0.31 & $1.62^{\mathrm{a}}$ & $12.54^{\mathrm{a}}$ & 0.28 & $11.26^{\mathrm{a}}$ & 0.28 & $2.14^{\mathrm{a}}$ \\
\hline June $(J)$ & 0.45 & $1.04^{\mathrm{a}}$ & 0.41 & $1.59^{\mathrm{a}}$ & $12.95^{\mathrm{a}}$ & 0.28 & $19.29^{\mathrm{a}}$ & 0.31 & $2.72^{\mathrm{a}}$ \\
\hline September $(\mathrm{S})$ & $0.50^{\mathrm{a}}$ & $0.64^{\mathrm{a}}$ & 0.40 & $1.57^{\mathrm{a}}$ & $6.33^{\mathrm{a}}$ & 0.45 & $15.70^{\mathrm{a}}$ & 0.33 & $2.52^{\mathrm{a}}$ \\
\hline December (D) & $1.55^{\mathrm{a}}$ & $0.85^{\mathrm{a}}$ & 0.38 & $1.30^{\mathrm{a}}$ & $8.52^{\mathrm{a}}$ & 0.28 & $20.63^{\mathrm{a}}$ & 0.28 & $3.55^{\mathrm{a}}$ \\
\hline
\end{tabular}

LC-MS/MS: liquid chromatography-tandem mass spectrometry; atotal concentration of pesticides that exceeds the allowed limit established by European Union $\left(<0.50 \mu \mathrm{g} \mathrm{L}^{-1}\right){ }^{25}$ Data summarized from the sum of the individual detailed results (Tables S3-S6 in the SI section). 
respectively. ${ }^{43}$ Those concentrations were lower than the observed in our study, that reached $6.54 \mu \mathrm{g} \mathrm{L} \mathrm{L}^{-1}$ for imazethapyr (SP 7 in June) and $0.80 \mu \mathrm{g} \mathrm{L}^{-1}$ for tebuconazole (SP 4 in September). Comparing the results reported in the literature with those obtained in the present paper, several samples had higher concentrations of pesticides, endorsing the contamination suspect.

Considering the EU guidelines for water quality standards for consumption, the maximum residue limit (MRL) for the total active ingredients is of $0.50 \mu \mathrm{g} \mathrm{L}^{-1}$ of pesticides, including metabolite degradations and reaction products. ${ }^{25,26}$ With regards to this, at least $58 \%$ of the samples analyzed in our study have a total concentration of pesticides higher than the recommended. However, it is important to highlight that only 12 pesticides of those 26 confirmed compounds in the screening stage were quantified, which means that the total concentration of pesticides can be even higher.

\section{Overall results and final considerations}

PCA analysis (Figure 3) was carried out in order to evaluate the contribution of all the variables under study $(\mathrm{pH}$, conductivity, color, turbidity and pesticide concentrations) taking into account the SP location and the period of collection $(\mathrm{M}, \mathrm{J}, \mathrm{S}$ and $\mathrm{D})$, allowing a reduction of the data matrix size. ${ }^{44}$ The variables with high importance in the multivariate analysis model were diuron, imazaquim, imazethapyr and color, while tebuthiuron, hexazinone and azoxystrobim presented less importance.

More similarities were expected within the collection period due to the crop season, rain activity and runoff, than for SP. However, in the 3D PCA plot, the opposite behavior was observed, with groups formed by specific samples like SP 4, SP 5 and 7, SP 9, whereas the other SP (1, 2, 3, 6 and $8)$ remained in the same group. This association indicates that the contamination of these areas may have been influenced by factors beyond the mere seasonal agricultural activities of the area. SP 5 (M, J, S, D) and SP 7 (M, J, S, D), for example, presented high concentrations of diuron and imazethapyr in all the collections, compared to others and remained as a single group. According to the GUS index, imazethapyr has a higher potential of leachability than diuron. ${ }^{39}$ Taken into account that the main use of diuron is for the weed control in sugarcane or citrus cultivation areas, ${ }^{9}$ crops that are not cultivated in the study area, the high incidence of this herbicide on the water over all the year is alarming.

In the screening step, the samples SP 4 and 9 were considered as highly contaminated due to the presence of several pesticides. After the multivariate analysis

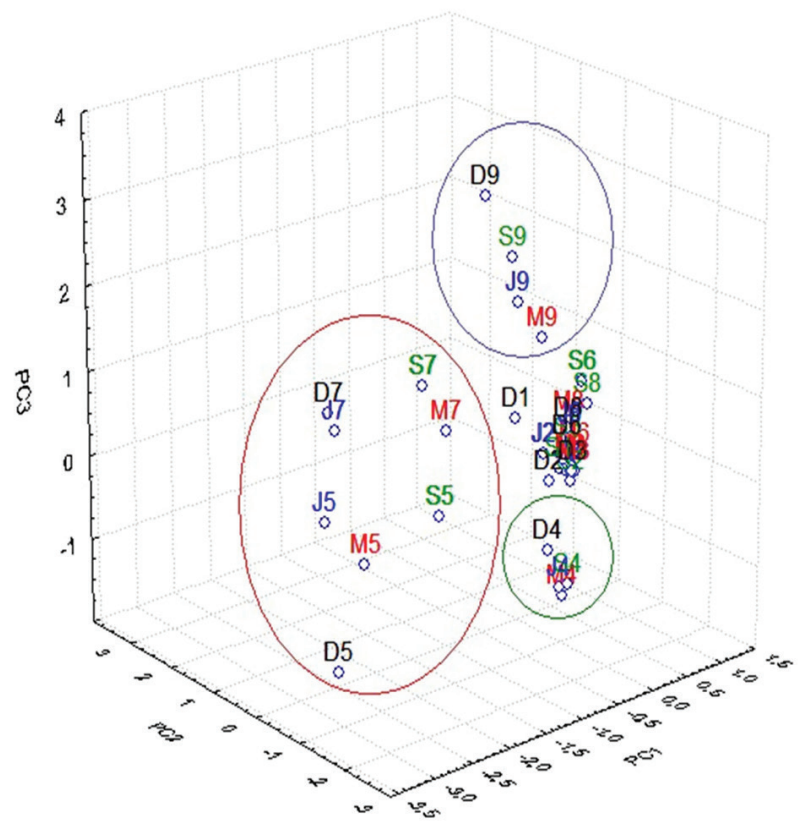

Figure 3. 3D view of principal component analysis (PCA) of water samples collected in 4 different months (March, June, September and December) of a year in 9 sampling points.

(Figure 3), it was observed that the same sampling points for the four collection campaigns were separated in some isolated groups. This behavior showed to be consistent with that previously observed, however, if it is considered the total amount of the pesticides quantified per samples, SP 5 and 7 are more contaminated than SP 4 and 9. It is important to consider that SP 5 is under a permanent preserved area, which ideally should have less environmental impacts. In the same way, SP 9 was collected from a groundwater well, which is the source of water commonly used in many cities and rural properties, almost without prior treatment before consumption.

The only sample recommended for human consumption that attends the EU guideline criteria, considering the parameter evaluated, was SP 8 in all campaigns. However, it is important to highlight that the current quality standards from drinking water, surface and groundwater, proclaimed by Brazilian legislation, could be easier to meet if the water sources and spring area were clean and preserved. On the other hand, the current legislation still does not guarantee the water quality regarding the absence of all pesticides in use and in non-hazardous amounts to human health. According to the article 11 of resolution No. 357/2005 from CONAMA:21 "The public powers may, at any moment, add other conditions and quality standards for a specific water body or make them more restrictive due to local conditions or based on scientific evidence". In this way, this study is expected to be a warning, contributing in 
the direction of public policies change, which need to be more concerned about the environmental monitoring. In addition, this work also shows the requirement of future studies in the area using biological indicators through ecotoxicological and toxicological tests, targets of our next studies.

\section{Conclusions}

Evidences of "water bodies" contaminations in the area were observed by the high conductivity values and the presence of pesticides, with confirmation by the screening and the quantitation of 12 pesticides in all the studied samples, including drinking water (SP 8). High concentrations of diuron and imazethapyr in surface and groundwater drew more attention when compared to other regions. However, the absence of legislation for these compounds, like many others, makes difficult the prohibition or control of the use and the residue level.

The high levels of contamination in a permanent preserved area, water bodies and groundwater are concerning, encouraging further assessment and monitoring of this area, and bring subsidies for discussions on changes in the parameters evaluated by the legislation and for the management of natural resources by the competent authorities.

\section{Supplementary Information}

Supplementary information is available free of charge at http://jbcs.sbq.org.br as PDF file.

\section{Acknowledgments}

The authors are thankful to Ministério Público do Trabalho do Paraná for their help in the area selection and sampling and Waters Technologies of Brazil for the analysis support. This study was financed in part by the Coordenação de Aperfeiçoamento de Pessoal de Nível Superior-Brasil (CAPES)-Finance Code 001 for doctoral fellowships in Chemistry-UEL. We would like to thank also CAPES (project No. 88881.068504/2014-01, PROCAD/2013, public notice 071/2013, process No. 3007/2014) for financial support providing the chromatographic column and (project No. AUX-PE-NANOBIOTEC-710/2009 process Nanobio 23/2008 No. 23038.019085/2009-14) for the LC-MS/MS. Our gratitude also to Conselho Nacional de Desenvolvimento Científico e Tecnológico- Brazil (CNPq) by the fellowships - Bolsa Produtividade DT-2 Química (Processo No. 309762/2017) and PIBIC.

\section{References}

1. Pedlowski, M. A.; Canela, M. C.; Terra, M. A. C.; de Faria, R. M. R.; Crop. Prot. 2012, 31, 113.

2. Barbosa, A. M. C.; Solano, M. L. M.; Umbuzeiro, G. A.; Front. Public Health 2015, 3, 246.

3. Piccoli, C.; Cremonese, C.; Koifman, R. J.; Koifman, S.; Freire, C.; Environ. Res. 2017, 151, 389.

4. Silvério, A. C. P.; Machado, S.C.; Azevedo, L.; Nogueira, D. A.; Graciano, M. M. C.; Simões, J. S.; Viana, A. L. M.; Martins, I.; Environ. Toxicol. Pharmacol. 2017, 55, 99.

5. Cattelan, M. D. P.; Maurer, P.; Garcia, F.; Berro, L. F.; Machado, M. M.; Manfredini, V.; Piccoli, J. C. E.; Life Sci. 2018, 203, 177.

6. Ministério da Saúde; Relatório Nacional de Vigilância em Saúde de Populações Expostas a Agrotóxicos, available at http://bvsms.saude.gov.br/bvs/publicacoes/agrotoxicos_otica_ sistema_unico_saude_v1_t.1.pdf, accessed in April 2019.

7. Sparovek, G.; Barreto, A. G. O. P.; Matsumoto, M.; Berndes, G.; Environ. Sci. Technol. 2015, 17, 10285.

8. Felsot, A. S.; Racke, K. D.; Hamilton, D. J.; Rev. Environ. Contam. Toxicol. 2003, 177, 123.

9. Felicio, A. L. S. M.; Monteiro, A. M.; Almeida, M. B.; Madeira, T. B.; Nixdorf, S. L.; Yabe, M. J. S.; An. Acad. Bras. Ciênc. 2016, 88, 1235.

10. Bolognesi, C.; Mutat. Res. 2003, 543, 251.

11. Campos, E.; dos Santos, V. P. S.; Sarpa, M. C. M.; Barros, U. O.; Neurotoxicology 2016, 56, 7.

12. Landau-Ossondo, M.; Rabia, N.; Jos-Pelage, J.; Marquet, L. M.; Isidore, Y.; Saint-Aimé, C.; Martin, M.; Irigaray, P.; Belpomme, D.; Biomed. Pharmacother. 2009, 63, 383.

13. Rousis, N. I.; Bade, R.; Bijlsma, L.; Zuccato, E.; Sancho, J. V.; Hernandez, F.; Castiglioni, S.; Environ. Res. 2017, 156, 31.

14. Salvia, M. V.; Jrad, A. B.; Raviglione, D.; Zhou, Y.; Bertrand, C.; Environ. Sci. Pollut. Res. 2017, 1, 7.

15. Sposito, J. C. V.; Montagner, C. C.; Casado, M.; Navarro-Martín, L.; Jut Solórzano, J. C.; Piña, B.; Grisolia, A. B.; Chemosphere 2018, 209, 696.

16. Kim, K. H.; Kabir, E.; Jahan, S. A.; Sci. Total Environ. 2017, $575,525$.

17. Brouwer, M.; Huss, A.; Van der Mark, M.; Nijssen, P. C. G.; Mulleners, W. M.; Sas, A. M. G.; Van Laar, T.; de Snoo, G. R.; Kromhout, H.; Vermeulen, R. C. H.; Environ. Int. 2017, 107, 100.

18. Gunier, R. B.; Kang, A.; Hammond, S. K.; Reinier, K.; Lea, C. S.; Chang, J. S.; Does, M.; Scelo, G.; Kirsch. J.; Crouse, V.; Cooper, R.; Quinlan, P.; Metayer, C.; Environ. Res. 2017, 156, 57.

19. http://www.agricultura.gov.br/noticias/valor-da-producaoagropecuaria-de-2018-e-de-r-516-6-bilhoes accessed in April 2019. 
20. Mekonen, S.; Argaw, R.; Simanesew, A.; Houbraken, M.; Senaeve, D.; Ambelu, A.; Spanoghe, P.; Chemosphere 2016, $162,252$.

21. Agência Nacional de Vigilância Sanitária (ANVISA); Dispõe sobre A Classificação dos Corpos de Água e Diretrizes Ambientais para o seu Enquadramento, bem como Estabelece as Condições e Padrões de Lançamento de Efluentes, e Dá outras Providências, Resolução RE No. 357 de 17 de março de 2005, Brasil.

22. World Health Organization (WHO); Protecting Surface Water for Health. Identifying, Assessing and Managing Drinking-Water Quality Risks in Surface-Water Catchments; World Health Organization: Geneva, Switzerland, 2016, available at https://apps.who.int/iris/bitstream/hand le/10665/246196/9789241510554-eng.pdf;jsessionid=1B3C2 3B6F890126BE05CDA06EFCAF153?sequence=1, accessed in April 2019.

23. Ministério da Saúde; Dispõe sobre Os Procedimentos de Controle e de Vigilância da Qualidade da Água para Consumo Humano e seu Padrão de Potabilidade, Portaria MS No. 2.914, de 12 de dezembro de 2011, Brasil.

24. Lei dos Agrotóxicos No. 7802 of 1989, Brasil, available at www.planalto.gov.br/ccivil_03/LEIS/L7802.htm, accessed in April 2019.

25. European Commission (EC); Regulation (EC) No. 396/2005 of the European Parliament and of the Council of 23 February 2005 on Maximum Residue Levels of Pesticides in or on Food and Feed of Plant and Animal Origin and Amending, Council Directive 91/414/EEC. OJ L 70, 16.3.2005, p. 1-16.

26. Narita, K.; Matsui, Y.; Iwao, K.; Kamata, M.; Matsushita, T.; Shirasaki, N.; Environ. Int. 2014, 63, 114.

27. Avelhan, B. L.; Zylbersztajn, D.; RAUSP Manage. J. 2018, 53, 178.

28. Ministério Público do Estado Paraná, available at https://mp-pr. jusbrasil.com.br/noticias/360765/mp-retoma-investigacao-noribeirao-dos-apertados-mp-retoma-investigacao-em-arapongas, accessed in April 2019.

29. Lopes, M. N. T.; Netto, P. T.; Lourencetti, C.; Marchi, M. R. R.; Ribeiro, M. L.; Pesticidas 2011, 21, 103.

30. Morphet, J.; Hancock, P.; A Rapid Method for Screening and Confirmation of over 400 Pesticides Residues in Food; Waters Application Note, No. 720002628en, 2008, https://www. gimitec.com//file/720002628en.pdf, accessed in April 2019.
31. European Commission (EC); SANCO/12571/2013: Guidance Document on Analytical Quality Control and Validation Procedures for Pesticides Residues Analysis in Food and Feed, SANCO/12571/2013, European Commission Health \& Consumer Protection Directorate-General and Safety of the Food Chain Chemicals, Contaminants, and Pesticides, available at http://www.eurl-pesticides.eu/library/docs/allcrl/ AqcGuidance_Sanco_2013_12571.pdf.

32. Statistica Software; StatSoft, Tulsa, OK, USA, 2004.

33. Fundação Nacional de Saúde (FUNASA); Manual de Controle da Qualidade da Água para Técnicos que Trabalham em ETAS; Ministério da Saúde: Brasília, Brasil, 2014.

34. Alam, M. J. B.; Islam, M. R.; Muyen, Z.; Mamun, M.; Islam, S.; Int. J. Environ. Sci. Technol. 2007, 4, 159.

35. Chagas, F. B.; Rutkoski, C. F.; Bieniek, G. B.; Vargas, G. D. L. P.; Hartmann, P. A.; Hartmann, M. T.; Acta Limnol. Bras. 2017, 29, e14.

36. Armas, E. D.; Monteiro, R. T. R.; Antunes, P. M.; Santos, M. A. P. F.; Camargo, P. B.; Abakerli, R. B.; Quim Nova 2007, 30, 1127.

37. https://www.agilent.com/cs/library/applications/5991-1183EN. pdf, accessed in January 2019.

38. Ribani, M.; Bottoli, C. B. G.; Collins, C. H.; Jardim, I. C. S. F.; Melo, L. F. C.; Quim. Nova 2004, 27, 771.

39. http://npic.orst.edu/ingred/ppdmove.htm, accessed in January 2019.

40. https://sitem.herts.ac.uk/aeru/ppdb/en/index.htm, accessed in January 2019.

41. Mansano, A. S.; Moreira, R. A.; Dornfeld, H. C.; Diniz, L. G. R.; Vieira, E. M.; Daam, M. A.; Rocha, O.; Seleghim, M. H. R.; Environ. Sci. Pollut. Res. 2016, 1, 12.

42. Howe, P. L.; Reichelt-Brushett, A. J.; Clark, M. W.; Seery, C. R.; J. Photochem. Photob., B 2017, 171, 125.

43. Silva, D. R. O.; Avila, L. A.; Agostinetto, D.; Dal Magro, T.; Oliveira, E.; Zanella, R.; Noldin, J. A.; Ciência Rural 2009, 39, 2383.

44. Palma, P.; Kuster, M.; Alvarenga, P.; Palma, V. L.; Fernandes, R. M.; Soares, A. M. V. M.; López de Alda, M. J.; Barcel, D.; Barbosa, I. R.; Environ. Int. 2009, 35, 545.

Submitted: November 13, 2018

Published online: April 18, 2019 